THE OTHER WORKER 



\section{THE OTHER WORKER}

A Comparative Study

of Industrial Relations

in the United States and Japan

BY ARTHUR M. WHITEHILL, JR. AND SHIN-ICHI TAKEZAWA

East-West Center Press Honolulu 
COPYRIGHT (C) 1968 BY EAST-WEST CENTER PRESS
UNIVERSITY OF HAWAII

ALL RIGHTS RESERVED

LIBRARY OF CONGRESS CATALOG CARD NUMBER: $6{ }^{7}-21409$ 